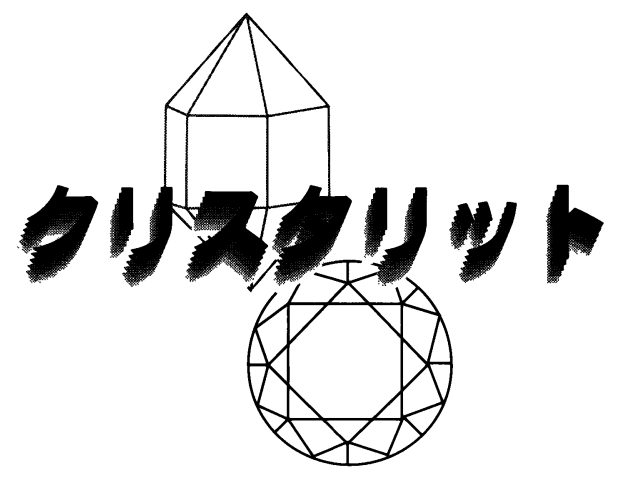

選択毒性

\section{Selective Toxicity}

特定の対象生物にだけ発揮される毒性のこと. 例えば抗 生物質であるぺニシリンは病原性細菌に毒性をもつ一方, ヒトの細胞には無毒である.これは動物にはなく細菌だけ がもつ細胞壁に作用して, 細胞壁合成を阻害することで特 定の細菌を死滅させるためである. 選択毒性の概念を初め て明確に打ち出したのはPaul Ehrlich といわれている.

(熊本大学環境安全センター 山口佳宏)

\section{カルパペネム薬 \\ Carbapenem}

ペニシリンと同様に $\beta$-ラクタム環を基本骨格とする $\beta$ ラクタム環系抗生物質の一種. 抗菌スペクトルが広く, 院 内感染症で最も重要である緑膿菌や嫌気性菌を含む広範 囲の菌に有効である．また細菌が産生する $\beta$-ラクタム環 を加水分解する $\beta$-ラクタマーゼによって加水分解されに くいことから, $\beta$-ラク夕ム環系抗生物質の中でも切り札的 な存在として臨床で扱われている.

(熊本大学環境安全センター 山口佳宏)

\section{トポロジー的共鳴エネルギー Topological Resonance Energy}

鎖状ポリエンには，原子化熱 (分子を原子に分解するの に必要なエネルギー)の加成性が成り立つ.すなわち, $\mathrm{C}=\mathrm{C}, \mathrm{C}-\mathrm{C}, \mathrm{C}-\mathrm{H}$ 結合の結合エネルギーを, 534.31, 419.70, $428.15 \mathrm{~kJ} / \mathrm{mol}$ と仮定し, 構造式中の結合のエネルギーを 足したものが, 実測の原子化熱にほぼ等しくなる.

ベンゼンなどの環状ポリエンについては加成性が成り 立たなくなる，C=C, C-C, C-H 結合でできた仮想的なべ ンゼンの推定される原子価熱よりも, 実測のベンゼンの原 子化熱のほうが高い.この差をデュワー共鳴エネルギー (DRE) と呼ぶ.

上記 $3 つ の$ 結合エネルギーは, 平面分子に対して仮定さ れたものであるため, 非平面の環状共役系において DRE を考慮できない.ヒュッケル分子軌道法により実際の分子 と C=C, C-C, C-H 結合でできた仮想分子のエネルギーを 求め, その差をトポロジー的共鳴エネルギー (TRE) と呼
んでいる. $\pi$ 電子系の安定性の指標として用いられている. 1976 年, 相原惇一教授により定義された。

(科学技術振興機構 ERATO中村活性炭素クラスタープロジエクト 松尾 豊)

\section{フィコビリン \\ Phycobilin}

紅藻, ラン藻, クリプト藻, 灰色植物に見られる光合成 色素の一群で, 基本骨格に開環テトラピロール（ビリン） をもつ. ヘムの代謝によって生じた前駆体ビリベルジン IX $\alpha$ からさまざまな部位が還元されることによって, 色調 を異にする多様な色素群が合成される。これらのうち, フ イコシアノビリンとフィコエリスロビリンについては合 成に関与する酵素が明らかになっているが, フィコウロビ リンとフィコビリビオリンについては不明なままである. 紅藻やラン藻では, フィコビリンを発色団としてチオエー テル結合したタンパク質(フィコビリタンパク質) とリン カータンパク質が会合して,巨大タンパク質複合体フィコ ビリソームをチラコイド膜上に形成する.フィコビリソー ムは光エネルギーを光化学系II 複合体へと送るアンテナ として機能する.フィコビリンはクロロフィルがあまり吸 収できない緑色光を吸収できるので, フィコビリンをもつ 生物種では, より広い波長領域の光を利用して光合成を行 うことができる。

(久留米大学医学部 杉島正一)

\section{フィトクロム \\ Phytochrome}

1959 年に Borthwickらによって発見された植物に広く 存在する赤・遠赤色光受容体タンパク質で, 発色団として フィトクロモビリンをチオエーテル結合している. 赩光 (650 nm 付近) を受容することで生じる発色団の異性化反 応をトリガーとして, タンパク質全体の Pr 型 (不活性型) から Pfr 型 (活性型) への構造变化, 逆に遠赤色光 $(730 \mathrm{~nm}$ 付近)の受容によって Pfr 型から Pr 型への可逆的な变化を 示す.フィトクロムは種子発芽, 花芽形成, 生物時計, 形 態形成などさまざまな生理反応を調節しているが，その機 能発現の分子機構は不明な点が多く, 現在はリン酸化酵素 として働き, シグナル伝達を行うという説や, Prから Pfr への変化に伴って, 細胞質から核内へ移行し, 転写反応に 関与するという説などが提唱されている.フィトクロムの 立体構造は長らく不明であったが, 2005 年に細菌フィト クロムホモログの発色団結合ドメインの構造が明らかと なった。

(久留米大学医学部 杉島正一) 


\section{レクチン \\ Lectin}

レクチンはもともと植物種子中に見出された赤血球凝 集活性を示すタンパク質の一群であり，それぞれ特異的な 糖鎖を認識し結合する.レクチンには通常 2 力所以上の糖 結合部位が存在していることから, 細胞表面の糖鎖と結合 した場合，それらを架橋することによって細胞凝集活性を 示す.レクチンの中には, 細胞凝集活性のほかに, リンパ 球を刺激して分裂・増殖を引き起こす活性 (マイトジェン 活性）や細胞障害活性などさまざまな活性を示すものがあ るが,これらはレクチンと細胞表面の特異的糖鎖との結合 によって引き起こされるものと考えられている。近年で は, 動物の組織や体液中からも共通のレクチンドメインを 有するタンパク質が多数見出されており, タンパク質の細 胞認識や細胞接着に重要な役割を果たしていることが明 らかになっている.レクチンは特異的な糖結合活性を示す ことから, 糖タンパク質や糖脂質の検出や精製，また最近 では複数の異なる特異性をもつレクチンとの結合性を基 に, 糖鎖構造解析などにも用いられている.

(長崎大学工学部 畠山智充)

\section{リシン \\ Ricin}

リシンはヒマ(トウゴマ；Ricinus communis) 種子中に 存在する強力な毒性を示すレクチンであり, 真核細胞 $28 \mathrm{~S}$ rRNAの 1 力所 (4324 番目)のアデニンとリボースの間を 特異的に切断する酵素サブユニット $(\mathrm{A}$ 鎖) とガラクトー スとの結合性を示すレクチンサブユニット（B 鎖）からな る.リシンの細胞毒性は, B 鎖が細胞表面糖鎖と結合した 後に, $\mathrm{A}$ 鎖が細胞膜を通過してサイトソル内でリボソーム を不活性化し，タンパク質合成を阻害することによる。リ シンと類似した䏝性レクチンとしては,トウアズキ (Abrus precatorius）種子中のアブリンなどがある.リシン B 鎖の 立体構造は $\beta$-trefoil 構造として知られており, 類似した立 体構造をもつドメインが, レクチン以外にもさまざまな酵 素や毒素の一部として見出されている。一方，B 鎖をもた ない $\mathrm{A}$ 鎖のみの形で存在するリボソーム不活性化タンパ ク質も植物中に広く存在することが知られているが，それ らはB 鎖をもたないために細胞自体に対する毒性は示さ ない。

（長崎大学工学部 畠山智充） 